\title{
Improving Student Learning Outcomes in Natural Science Learning Through Image Cutouts in Class V
}

\author{
Siti Nurasih \\ SDN SRENGSENG 01 \\ sitinurasih144@gmail.com
}

\section{Article History}

accepted 01/11/2020

approved 08/11/2020

published $15 / 11 / 2020$

\begin{abstract}
The research conducted is to improve the learning outcomes of students in learning. Student learning outcomes are very influential on the delivery of learning and the way the learning is carried out, in learning supporting media is needed to support learning success. This research is a classroom action research (PTK) obtained from the results of research on teacher activity through 3 cycles, namely in cycle I with an average value of 57 (less) and in cycle II to 69 (sufficient), while in cycle III it has increased by 78, 8 (good). Student learning outcomes obtained in science learning, namely, cycle I and cycle II the value has not been completed because it has not reached the KKM, while in cycle III with the use of cutout media in learning, there were 18 students with an average value of 78.8 or $86 \%$. have reached KKM and 3 students have not reached the minimum completeness. Based on the results of the data analysis, it can be concluded that the use of cutout media can improve student learning outcomes in science learning in class V SDN Srengseng 01.
\end{abstract}

Keywords: learning outcomes, research, cutout media

\begin{abstract}
Abstrak
Penelitian yang dilakukan adalah untuk meningkatkan hasil belajar peserta didik dalam pembelajaran. Hasil belajar siswa sangat berpengaruh pada penyampaian pembelajaran dan cara pelaksanaan pembelajaran yang dilakukan, dalam pembelajaran dibutuhkan media pendukung untuk menunjang keberhasilan belajar. Penelitian ini merupakan penelitian tindakan kelas (PTK) yang diperoleh dari hasil penelitian aktivitas guru melalui 3 siklus yaitu pada siklus I dengan nilai rata-rata 57 (kurang) dan pada siklus II menjadi 69 (cukup), sedangkan pada siklus III mengalami peningkatan 78,8 (baik). Hasil belajar siswa yang diperoleh pada pembelajaran IPA yaitu, siklus I dan siklus II nilai tersebut belum tuntas karena belum mencapai $\mathrm{KKM}$, sedangkan pada siklus III dengan penggunaan media potongan gambar dalam pembelajaran menunjukan sebanyak 18 siswa dengan nilai rata-rata 78,8 atau $86 \%$ sudah mencapai KKM dan 3 siswa belum mencapai ketuntasan minimum. Berdasarkan hasil analisi data dapat disimpulkan bahwa penggunaan media potongan gambar dapat meningkatkan hasil belajar siswa pada pembelajaran IPA di kelas V SDN Srengseng 01.
\end{abstract}

Kata kunci: Hasil belajar, Penelitian, Media potongan gambar

Social, Humanities, and Education Studies (SHEs): Conference Series https://jurnal.uns.ac.id/shes

p-ISSN 2620-9284

e-ISSN 2620-9292 


\section{PENDAHULUAN}

Pendidikan merupakan suatu hal yang sangat penting di dalam kehidupan manusia. Pendidikan merupakan suatu sarana untuk mencapai manusia yang berkualitas dan berkarakter. Oleh karena itu, jalannya proses pendidikan harus diselingi dengan kualitas pendidik serta sarana prasarana yang memadai supaya tercipta pendidikan yang baik. Di dalam pendidikan terdapat istilah kegiatan belajar mengajar atau proses belajar mengajar yang disebut dengan pembelajaran. Pembelajaran adalah usaha terencana dan tersusun dengan cara memanipulasikan sumber-sumber belajar sehingga terjadi proses belajar dalam diri siswa.

Proses belajar mengajar pada hakikatnya adalah proses komunikasi, yaitu proses penyampaian pesan dari sumber pesan ke penerima pesan. Terkadang terjadi kendala dalam proses penyampaian pesan yang dilakukan oleh pendidik kepada peserta didik, hal ini dapat mengganggu tingkat pemahaman siswa terhadap suatu materi yang disampaikan oleh pendidik. Permasalahan yang terjadi pada proses belajar mengajar dapat diketahui dari hasil akhir pembelajaran yang merupakan tolak ukur dari keberhasilan suatu tujuan pembelajaran. Salah satu hasil belajar yang biasa dijadikan tolak ukur adalah nilai. Proses belajar mengajar dikatakan gagal apabila hasil akhir yang diperoleh siswa melalui tes tidak sesuai dengan tujuan pembelajaran yang ingin dicapai.

Keberhasilan suatu proses pembelajaran sangat ditentukan oleh guru, siswa dan lingkungan sekolah. Ketiga hal ini tidak dapat dipisahkan karena ketiganya saling terkait satu dengan yang lain. Walaupun guru sudah menerangkan secara panjang lebar mengenai suatu materi namun belum tentu semua siswa dapat menerima dengan baik. Hal ini dikarenakan tidak semua siswa dapat menerima pelajaran jika hanya diterangkan melalui metode ceramah. Oleh karena itu, guruguru harus berinovasi untuk memberikan pembelajaran yang menyenangkan, tidak membosankan dan tentunya dapat dengan mudah diterima oleh semua siswa. Salah satu cara untuk membuat pembelajaran menjadi menyenangkan adalah dengan cara menggunakan media pembelajaran. Penggunaan media pembelajaran dapat membuat hal yang bersifat abstrak menjadi lebih konkrit dan membuat suasana belajar yang tidak menarik menjadi lebih menyenangkan. Banyak media pembelajaran yang ada, namun belum semua digunakan dan tidak menciptakan media pembelajaran yang lebih menyenangkan. Media pembelajaran yang peneliti gunakan yaitu media potongan gambar. Dengan menggunakan media potongan gambar diharapkan siswa menjadi lebih mudah menerima pelajaran IPA yang akhirnya membuat hasil belajar siswa menjadi meningkat. Media potongan gambar diharapkan mampu menjadi media pembelajaran yang dapat membuat siswa lebih mudah menerima pelajaran IPA dan membuat hasil belajar

Berdasarkan uraian permasalahan di atas, maka peneliti ingin melihat bagaimanakah tingkat ketuntasan belajar siswa dengan penggunaan media potongan gambar dalam pembelajaran IPA pada tema ekosistem di kelas V SDN Srengseng 01. Oleh karena itu peneliti akan mengkajinya secara lebih mendalam dalam penelitian yang berjudul: "Peningkatan Hasil Belajar Siswa pada Pembelajaran IPA Melalui Media Potongan Gambar di Kelas V."

\section{METODE}

Metode yang digunakan dalam penelitian adalah metode Penelitian Tindakan Kelas (classroom action research). Subjek dalam penelitian ini adalah siswa kelas V SDN Srengseng 01 yang berjumlah 21 orang siswa, yang terdiri dari 11 orang siswa lakilaki dan 10 orang orang siswi perempuan. Penelitian ini dilaksanakan di SDN 
Srengseng 01. Pada tanggal 30 Oktober 2020 sampai dengan 07 November 2020. Adapun penelitian ini dilaksanakan pada semester 1 tahun ajaran 2020/2021. Adapun teknik pengumpulan data dalam penelitian ini observasi dan tes.

\section{HASIL DAN PEMBAHASAN}

Penelitian ini dilakukan di SDN Srengseng 01 dengan subjek penelitian 21 siswa. Penelitian dilaksanakan dari tanggal 30 Oktober sampai 07 November 2020. Analisis hasil penelitian ini dilakukan dengan menggunakan rumus rata-rata dan persentase untuk mendeskripsikan pengamatan hasil tes akhir. Post tes digunakan untuk mengetahui kemampuan siswa setelah mendapatkan pembelajaran melalui media potongan gambar yang digunakan. Penelitian ini dilakukan dalam dua siklus yang terdiri dari beberapa tahap yang akan diuraikan dibawah ini:

\section{Siklus I}

\section{a. Planning (Perencanaan)}

1. Menyusun perbaikan pembelajaran

2. Menyiapkan gambar

3. Menyusun instrumen observasi

4. Menyusun instrumen penelitian

b. Acting (Pelaksanaan)

1. Guru memberikan materi tentang rantai makanan

2. Guru melakukan tanya jawab untuk mengukur pemahaman materi

3. Guru memberikan tugas soal

4. Guru bersama siswa membahas tugas

\section{c. Observasing (Pengamatan)}

1. Pemahaman siswa tentang menyebutkan kelompok-kelompok yang termasuk produsen,konsumen 1,konsumen 2,konsumen puncak dan pengurai

2. Keaktifan siswa dalam tanya jawab

3. Keseriusan siswa dalam mengerjakan tugas

Tabel 1. Hasil siklus I

\begin{tabular}{cccc}
\hline No & Nama Siswa & Nilai siklus I & Keterangan \\
\hline 1 & Afkarina & 50 & Kurang \\
2 & Zaky & 70 & Cukup \\
3 & Misbakhul & 70 & Cukup \\
4 & Zaky Al Amin & 50 & Kurang \\
5 & Muzayin & 50 & Kurang \\
6 & Feniza & 60 & Kurang \\
7 & Algif & 40 & Kurang \\
8 & Galih & 40 & Kurang \\
9 & Aryanti & 70 & Cukup \\
10 & Indra & 50 & Kurang \\
11 & Tiara & 40 & Kurang \\
12 & Prames & 70 & Cukup \\
13 & Najmi & 50 & Kurang \\
14 & Raffi & 80 & Baik \\
15 & Jasinda & 50 & Kurang \\
16 & Marsya & 50 & Kurang \\
17 & Mayfan & 60 & Kurang \\
18 & Raisa & 70 & Cukup \\
19 & Alfatih & 70 & Kurang \\
20 & Shalsa & 50 & \\
\hline
\end{tabular}


SHEs: Conference Series 3 (3) (2020) $62-73$

\begin{tabular}{cccc}
\hline 21 & Zulfa & 50 & Kurang \\
& Jumlah & 1190 & \\
Rata-rata & 57 & \\
\hline
\end{tabular}

Berdasarkan tabel di atas dapat diketahui bahwa pada siklus I sudah ada 7 siswa yang tuntas belajarnya yaitu 33\%. Sedangkan siswa yang tidak tuntas ada 14 siswa yaitu $67 \%$. Berdasarkan KKM yang ditetapkan di SDN Srengseng 01 bahwa seorang siswa dikatakan tuntas belajarnya bila memiliki nilai ketuntasan secara individu minimal 70 dan ketuntasan secara klasikal $80 \%$ siswa di kelas tersebut tuntas belajarnya. Oleh karena itu, dapat disimpulkan bahwa ketuntasan belajar siswa secara klasikal untuk siklus I belum tuntas.

\section{Siklus II}

\section{a. Planning (Perencanaan)}

1. Menyusun perbaikan pembelajaran

2. Menyiapkan gambar

3. Menyusun instrumen observasi

4. Menyusun instrumen penelitian

d. Acting (Pelaksanaan)

1. Guru memberikan materi tentang rantai makanan

2. Guru melakukan tanya jawab untuk mengukur pemahaman materi

3. Guru memberikan tugas soal

4. Guru bersama siswa membahas tugas

e. Observasing (Pengamatan)

1. Pemahaman siswa tentang menyebutkan kelompok-kelompok yang termasuk produsen,konsumen 1,konsumen 2,konsumen puncak dan pengurai

2. Keaktifan siswa dalam tanya jawab

3. Keseriusan siswa dalam mengerjakan tugas

\section{f. Reflecting ( Refleksi)}

1. Pada siklus II peneliti melihat bahwa hasil yang telah dicapai oleh siswa belum sesuai harapan peneliti karena belum berhasil dengan maksimal.

2. Siswa kurang memahami materi tentang rantai makanan

3. Siswa kurang aktif dalam tanya jawab

4. Siswa kurang serius dalam mengerjakan tugas

5. Nilai KKM yang ditentukan 70

6. Nilai siswa belum diatas KKM

7. Nilai rata-rata 69

Tabel 2. Hasil siklus II

\begin{tabular}{cclc}
\hline No & Nama Siswa & Nilai siklus II & Keterangan \\
\hline 1 & Afkarina & 65 & Cukup \\
2 & Zaky & 75 & Baik \\
3 & Misbakhul & 80 & Baik \\
4 & Zaky Al Amin & 70 & Cukup \\
5 & Muzayin & 70 & Cukup \\
6 & Feniza & 70 & Cukup \\
7 & Algif & 70 & Cukup \\
8 & Galih & 50 & Kurang \\
9 & Aryanti & 75 & Baik \\
10 & Indra & 65 & Cukup \\
11 & Tiara & 50 & Cukup \\
12 & Prames & 80 & Baik \\
13 & Najmi & 70 & Cukup \\
14 & Raffi & 85 & Baik \\
\hline
\end{tabular}


SHEs: Conference Series 3 (3) (2020) $62-73$

\begin{tabular}{lccc}
\hline 15 & Jasinda & 65 & Cukup \\
16 & Marsya & 65 & Cukup \\
17 & Mayfan & 70 & Cukup \\
18 & Raisa & 80 & Baik \\
19 & Alfatih & 80 & Baik \\
20 & Shalsa & 65 & Cukup \\
21 & Zulfa & 65 & Cukup \\
& Jumlah & 1445 & \\
& Rata-rata & 68 & \\
\hline
\end{tabular}

Berdasarkan tabel di atas dapat diketahui bahwa pada siklus II sudah ada 11 siswa yang tuntas belajarnya yaitu $52 \%$. Sedangkan siswa yang tidak tuntas ada 10 siswa yaitu 48\%. Berdasarkan KKM yang ditetapkan di SDN Srengseng 01 bahwa seorang siswa dikatakan tuntas belajarnya bila memiliki nilai ketuntasan secara individu minimal 70 dan ketuntasan secara klasikal $80 \%$ siswa di kelas tersebut tuntas belajarnya. Oleh karena itu, dapat disimpulkan bahwa ketuntasan belajar siswa secara klasikal untuk siklus II belum tuntas.

\section{Siklus II}

\section{a. Planning (Perencanaan)}

1. Menyusun perbaikan pembelajaran

2. Menyiapkan gambar

3. Menyusun instrumen observasi

4. Menyusun instrumen penelitian

b. Acting (Pelaksanaan)

1. Guru memberikan materi tentang rantai makanan

2. Guru melakukan tanya jawab untuk mengukur pemahaman materi

3. Guru memberikan tugas soal

4. Guru bersama siswa membahas tugas

\section{c. Observasing (Pengamatan)}

1. Pemahaman siswa tentang menyebutkan kelompok-kelompok yang termasuk produsen,konsumen 1,konsumen 2,konsumen puncak dan pengurai

2. Keaktifan siswa dalam tanya jawab

3. Keseriusan siswa dalam mengerjakan tugas

d. Reflecting ( Refleksi)

1. Pada siklus II peneliti melihat bahwa hasil yang telah dicapai oleh siswa belum sesuai harapan peneliti karena belum berhasil dengan maksimal.

2. Siswa kurang memahami materi tentang rantai makanan

3. Siswa kurang aktif dalam tanya jawab

4. Siswa kurang serius dalam mengerjakan tugas

5. Nilai KKM yang ditentukan 70

6. Nilai siswa belum diatas KKM

7. Nilai rata-rata 78,8

Tabel 3. Hasil siklus III

\begin{tabular}{llll}
\hline No & Nama Siswa & Nilai Siklus III & Keterangan \\
\hline 1 & Afkarina & 75 & Baik \\
2 & Zaky & 85 & Baik \\
3 & Misbakhul & 90 & Baik sekali \\
4 & Zaky Al Amin & 80 & Baik \\
5 & Muzayin & 80 & Baik \\
\hline
\end{tabular}


SHEs: Conference Series 3 (3) (2020) $62-73$

\begin{tabular}{llll}
\hline 6 & Feniza & 80 & Baik \\
7 & Algif & 60 & Kurang \\
8 & Galih & 60 & Kurang \\
9 & Aryanti & 85 & Baik \\
10 & Indra & 80 & Baik \\
11 & Tiara & 60 & Kurang \\
12 & Prames & 90 & Baik sekali \\
13 & Najmi & 80 & Baik \\
14 & Raffi & 95 & Baik sekali \\
15 & Jasinda & 80 & Baik \\
16 & Marsya & 75 & Baik \\
17 & Mayfan & 80 & Baik \\
18 & Raisa & 90 & Baik sekali \\
19 & Alfatih & 90 & Baik sekali \\
20 & Shalsa & 70 & Cukup \\
21 & Zulfa & 70 & Cukup \\
& Jumlah & 1655 & \\
& Rata-rata & 78,8 & \\
\hline
\end{tabular}

Berdasarkan tabel di atas dapat diketahui bahwa pada siklus III sudah ada 18 siswa yang tuntas belajarnya yaitu $86 \%$. Sedangkan siswa yang tidak tuntas ada 3 siswa yaitun 14\%. Berdasarkan KKM yang ditetapkan di SDN Srengseng 01 bahwa seorang siswa dikatakan tuntas belajarnya bila memiliki nilai ketuntasan secara individu minimal 70 dan ketuntasan secara klasikal 80\% siswa di kelas tersebut tuntas belajarnya. Oleh karena itu, dapat disimpulkan bahwa ketuntasan belajar siswa secara klasikal untuk siklus III sudah tuntas.

\section{SIMPULAN}

Berdasarkan hasil pengolahan data tentang peningkatan hasil belajar siswa pada pembelajaran IPA melalui media potongan gambar pada tema ekosistem untuk meningkatkan hasil belajar siswa kelas V SDN Srengseng 01, dapat disimpulkan sebagai berikut:

1. Aktivitas siswa dalam proses pembelajaran IPA pada ekosistem melalui media potongan gambar pada siswa kelas V SDN Srengseng 01 adalah sebagai berikut: mendengar dan memperhatikan guru dalam menyampaikan tujuan dan langkah-langkah pembelajaran, menjelaskan materi tentang rantai makanan dan membagikan media potongan gambar pada setiap kelompok, membimbing siswa dalam menyusun ptongan gambar dan siswa menyusun puzzle, mempresentasikan hasil kerja kelompok, membuat kesimpulan tentang materi rantai makanan dan melakukan evaluasi dan refleksi.

2. Aktivitas guru dalam proses pembelajaran IPA pada tema ekosistem melalui media potongan gambar pada siswa kelas V SDN Srengseng 01 adalah sebagai berikut: melakukan apersepsi, memotivasi siswa, menyampaikan tujuan dan langkah-langkah pembelajaran, menjelaskan materi dan membagikan media potongan gambar, membimbing siswa dalam menyusun media potongan gambar berdasarkan LKS, meminta siswa mempresentasikan kerja kelompok masingmasing, meminta siswa menarik kesimpulan, mengecek pemahaman dan memberi umpan balik, memberikan soal evaluasi. 
Hasil belajar siswa pada siklus I yaitu 33\%,siklus II 52\% dan siklus III naik menjadi $86 \%$. Sehingga dapat disimpulkan bahwa peningkatan hasil belajar siswa melalui media potongan gambar dapat meningkatkan hasil belajar siswa.

\section{DAFTAR PUSTAKA}

Kunandar,(2012). Penelitian Tindakan Kelas, Jakarta: Rajawali Pers.

Wahidmurni,(2010). Evaluasi Pembelajaran Kompetensi dan Praktik, Yogyakarta:Nuha Letera. http://ansud-site.blogspot.com/2016/05/materi-tema-8kurikulum-2013- tentang.html. Diakses tanggal 12 febuari 2017.

Kunandar. 2012. Penelitian Tindakan Kelas. Jakarta: Rajawali Pers.

Slameto. 2010. Belajar dan Fator-Faktor yang Mempengaruhinya. Jakarta: PT Rineka Cipta.

Ahmad, Susanto. 2013. Teori belajar dan pembelajaran disekolah dasar. Jakarta: Kencana. 